\section{Det svingende sinn}

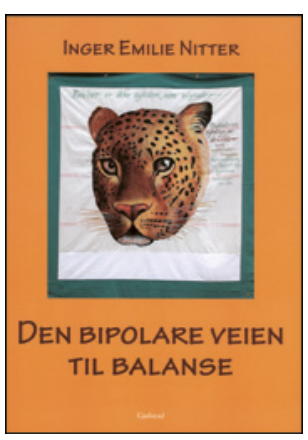

Inger Emilie Nitter

Den bipolare veien til balanse

173 s, ill. Rakkestad: Gjølstad Forlag, 2012

Pris NOK 200

ISBN 978-82-303-2129-4

Forfatteren er utdannet lærer. I 30-årsalderen fikk hun sterke stemningssvingninger av psykotisk karakter og etter hvert diagnosen bipolar lidelse. I denne boken forteller hun om sin oppvekst, sine parforhold og sine opphold i psykiatrisk sykehus. Boken er illustrert med vel 30 egenproduserte malerier med tilknytning til psykiatrien, kapitalismen og den vestlige sivilisasjonen.

Hun er vokst opp i Bærum med en far som var reklamesjef $i$ et forsikringsselskap, og en mor som var hjemmeværende. Foreldrene var aktive kristne, og de fleste venner av familien var knyttet til kirken. Måtehold og en viss strenghet var vanlig i hjemmet. For øvrig er det lite konkret man får vite om familien. Det er ingen opplysninger om overgrep eller store konflikter. Hun har åpenbart vært mest knyttet til sin far. «Jeg kommer ikke ordentlig nær mor. Jeg føler hun har død hud.»

Da hun forlater hjemmet, føler hun seg utrygg, innadvendt, umoden og mangler selvtillit. Hun blir lærer og videreutdanner seg i musikk og historie. Hun treffer en mann som er fortrolig med skog og fjell, gifter seg og får to døtre med denne «jegeren». Hun blir imidlertid jevnlig oppgitt og dypt fortvilet, og hun tror hun kan få det bedre alene. Hun rømmer hjem til sine foreldre, men mannen vil gjerne ha henne tilbake. Det blir imidlertid skilsmisse.

Siden får hun kontakt med en eldre kunstner, etterfulgt av et forhold til en dansk murer og siden en eldre fysiker, og pendler i perioder mellom disse. Men oftest forlater hun sine tidligere partnere etter kort stund, ikke sjelden etter en stormende krangel.

Hun opplever en rekke sykdomsperioder der hun blir tvangsinnlagt i Blakstad sykehus flere ganger, med til dels lengre opphold. Hun har også et opphold ved Modum Bads Nervesanatorium. Til slutt får hun uføretrygd.

Forfatteren ender åpenbart i konflikt med de fleste hun kommer i kontakt med, enten det er tidligere partnere eller terapeuter, det være seg sykepleiere, psykologer eller psykiatere.

Hun angriper kirken og psykiatrien som danner «enorme tankediktaturer». Hun protesterer mot tvang og ufrihet og mener at psykiatrien er for lite menneskelig. «Psykiatrisk behandling er tortur.» I senere år har hun også demonstrert offentlig mot psykiatrien.

På omslaget skriver Thomas Hylland Eriksen at «boken åpner for radikal nytenkning om sinnslidelser og psykiatri og ikke minst samfunnets verdigrunnlag», og Nina Witoszek skriver at «forfatteren tvinger oss til å se verden på en helt ny måte».

For meg er store deler en blanding av overfladiske biografiske skildringer og til dels usammenhengende avsnitt uten dypere mening. Jeg kan derfor ikke se at denne selvbiografien gir oss som lesere noe særlig av verdi, men det er et personlig standpunkt som andre åpenbart er uenig $\mathrm{i}$.

\section{Innsikt i livet med spiseforstyrrelse}

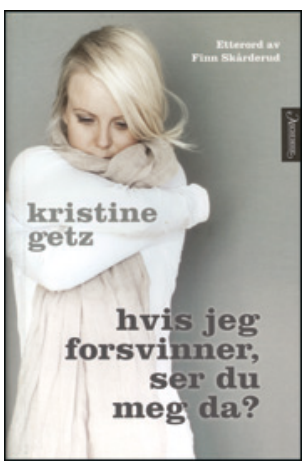

Kristine Getz

Hvis jeg forsvinner, ser du meg da?

240 s. Oslo: Aschehoug, 2012. Pris NOK 299

ISBN 978-82-03-23990-8

Her blir vi selvbiografisk servert en historie om spiseforstyrrelser. Forfatteren deler på modig vis sine svært personlige opplevelser og følelser i sin kamp for tilfriskning og et videre godt liv. Vi som ikke helt forstår hvordan det er å leve med dette, forstår litt bedre etter å ha lest. Hun bidrar til å avmystifisere en alvorlig sykdom, som spiller på sårbare marginer og høy kompleksitet.

Fagpersoner og pårørende vil ha stor nytte av boken. Mange pasienter vil kunne få hjelp til å komme videre. Også andre kan ha stor glede av den, og mange lesere vil kunne gjenkjenne vansker forfatteren beskriver, uten å ha samme diagnose eller omfang av vansker: behovet for kontroll, behovet for at livet har en plan, angsten for å miste grepet.

Oppbyggingen er kronologisk. I første del får man beskrevet et hjem fra Vestkant-Oslo som går i oppløsning. Forfatteren får store vansker med å håndtere dette, og etter hvert rømmer hun til Dublin. Vi blir med henne ut i studielivet, som arkitektstudent. Hun fremviser talenter de fleste av oss kan se langt etter. Hun lykkes, er godt likt og blir mer og mer perfeksjonistisk. Hun beskriver hvordan kroppen hennes blir kjørt ekstremt hardt, men sykdommen lar henne ikke forstå det. Så snur vinden med sykdommen. Ordet anoreksi dukker etter hvert opp, men forstår hun at hun faktisk er anorektiker? Det er utrolig hvordan hun dekker over vanskene og opprettholder funksjon frem til kollapsene skjer stadig hyppigere.

Vi møter foreldre, som forfatteren beskriver på godt og vondt, og en svært storsinnet kjæreste. Venner, studievenninner og besteforeldre er også med. Vi møter treningsinstruktører og helsepersonell som forfatteren gjør åpenbart narr av, men heldigvis senere også helsepersonell som har høstet stor respekt hos forfatteren.

Det er imponerende hvordan hun bretter ut sin spiseforstyrrelse, sin angst, sin skam. Hun er godt trent: Som et siste ledd i sin egenbehandling har hun blogget om vanskene sine på den åpne veven, og blitt svært populær med stor aktivitet her. Og hun skriver godt, beskriver dagene der hun kjemper, gir opp, kjemper, gir opp, dekker over, tyr til løgner, faller ut, kollapser, ønsker behandling, faller ut av behandling, kollapser, ønsker behandling igjen.

Tross omfanget av vanskene er teksten lettfattelig og underholdende. Alle handlinger er ikke like fornuftige, og man river seg $i$ håret. Hun beskriver seg selv med en herlig ironi, samtidig som hun klarer å understreke alvoret der hun står i sin spiseforstyrrelse, fullstendig uten sans for humor. Den konstante uroen må holdes under kontroll og tillater kun alvor og det å kjempe videre.

For deg som vil ha innsikt i hvordan det kan være å leve med en spiseforstyrrelse, er boken sterkt å anbefale. Faglig påfyll får du en smakebit av i Finn Skårderuds etterord.

Ola Amundsen

Ungdomshelsestasjonen

Moss 